\title{
[Review] \\ A Study on the Expansion of the Employment of the Elderly in Small Business: Focusing on the Opinions of Small Business Owners*
}

\author{
Beong-Sun YOO ${ }^{1}$
}

Received: March 23, 2020. Revised: April 24, 2020. Accepted: May 05, 2020.

\begin{abstract}
Purpose: The purpose of this study is to present a plan to expand the employment of the elderly in Small business as one of the ways to solve the problem of the supply and demand of the company due to the aging population and the problem of the elderly poverty. Research design, data and methodology: The method of this study is a qualitative research method, and the researcher visited a small and medium-sized company directly and collected data by conducting an in-depth interview with a business owner. The interview period was conducted on a total of 15 business owners from November 5, 2013 to November 18, 2013. Results: First, the reason why companies hire the elderly is because they are suitable people, and the reason why they are not employed is because the elderly are not suitable. Second, it was found that the most recruiting paths continued to work after retirement. Third, the strengths of the elderly in their businesses were diligence, integrity, leadership, wisdom, warmth, and skill. Disadvantages the elderly in their businesses include wanting to be treated as an adult, poor productivity, poor accuracy, and health risks. Fourth, in case of hiring the elderly, they were considering convergence with young employees, and it was suggested that there are no difficulties in being an elderly because the companies hiring the elderly use the elderly according to the characteristics of the elderly. Fifth, It is realistic to actively utilize the employment system after retirement. Sixth, it was found that, unlike young people, it is not easy to recruit people on the Internet, so it is necessary to improve the system. Lastly, some industries clearly distinguished between the jobs of the elderly and the jobs of the young, but in many industries, it was desirable to create jobs for the elderly by harmonizing the main and secondary jobs. Conclusion: Ultimately, the work of the elderly in small and mediumsized enterprises should be reborn as a high-quality job that can solve the poverty of the elderly by working as a regular worker in the enterprise, rather than simply working for the elderly.
\end{abstract}

Keywords : Elderly Employment, Small Buseness, Elderly Poperty Rate, Employment Status

JEL Classification Code : I30, J20, L10

\section{1. 서 론}

\footnotetext{
* This is abbreviated and partly modified from Yoo's Report(A Study on the Expansion of the Employment of the Elderly in Small Business in Gyeonggi Province)

1 Researcher, Gyeonggi Welfare Foundation, Korea. Email: sunmagnolia@hanmail.net

(c) Copyright: The Author(s)

This is an Open Access article distributed under the terms of the Creative Commons Attribution Non-Commercial License (http://Creativecommons.org/licenses/by-nc/4.0/) which permits unrestricted noncommercial use, distribution, and reproduction in any medium, provided the original work is properly cited.
}

우리나라의 고령화 진행속도는 세계 유래가 없을 정도로 빠르게 진행되고 있어 우리나라 인구 중 65 세 이상 인구 구성비는 2019 년 $14.9 \%$ 로 1970 년 3.1\%에 비해 5 배로 증가한 수준이며, 이후 계속 증가하여 2067 년 46.5\%로 증가될 것으로 전망되고 있다(Korea National Statistical Office, 2019). 급속한 고령화는 생산가능인구 감소, 노동생산성 하락, 재정부담 증가 등 다양한 경로를 통해 경제 전반에 부정적인 영향을 미치게 된다. 최근에 노인기준 연령을 65 세에서 70 세로 상향 조정하려는 움직임이나, 정년을 연장하고자 하는 움직임 등은 급격한 고령화의 충격을 줄이기 위한 노력이라고 볼 수 있다. 
우리사회의 인구고령화는 많은 사회적 문제를 야기하고 있는데 그 중에 하나는 바로 노인빈곤 문제이다. 다른 $\mathrm{OECD}$ 국가들의 평균 노인빈곤율이 $14.8 \%$ 인 것과 비교해 볼 때, 우리나라의 노인빈곤률은 47.5\%(OECD 기준: 전체인구 대상 가처분소득 중위값의 절반에 미달하는 가구 비율)로 노인빈곤율이 매우 높은 수준으로 나타나고 있다(OECD, 2018).

우리나라의 노인이 빈곤한 이유는 여러 가지가 있겠지만 가장 큰 이유는 국가의 연금제도 등이 정비되지 않은 상태에서 노후준비를 하지 못한 채 노후를 맞이하고 이와 동시에 가족부양의식이 약화되는 등 인구고령화, 사회보장제도, 노인부양변화 등이 함께 맞물렸기 때문이다. 산업화, 도시화, 사회적 규범변화로 인한 노인의 노동시장에서의 지위하락과 빈곤화는 대다수 선진국이 경험하였다. 다만 서구의 고령국가와 우리나라의 차이는 20 세기 초 서구는 노인빈곤문제 해결을 위한 연금제도 마련 등을 통해 복지국가로 전환하면서 노인빈곤문제를 해결하였다는 것이다. 이러한 사실은 사회보장제도의 발달이 상대적으로 미약했던 미국에서 조차도 사회보험제도 이후 노인의 생계형 근로가 줄고 노인빈곤이 완화되었다는 점에서 증명되고 있다.

사회보장제도가 미비하고 노후 준비를 하지 못한 우리나라 노인들은 노인이 되어도 생활비를 벌기 위해 일을 할 수 밖에 없는 것이 현실이다. 우리나라 중장년층의 은퇴준비지수는 54.5 점으로(Samsung Economic Research Institute, 2018) 경제적 준비를 포함한 노후준비가 되지 않은 경우가 많고 그렇기 때문에 노인이 되어도 일을 하는 경우가 많다. 우리나라의 공식적인 은퇴연령은 60 세로 통용되고 있으나, 우리나라 60-64 세 고용률은 59.4\%(OECD 514\%)로 세계 11 위, 65 세이상 노인고용율은 313\%(OECD14.9\%)로 세계 2 위를 차지하고 있어 노인근로가 많음을 알 수 있다(Asia Economy, 2019). 실제로 55-79 세 인구의 $58.5 \%$ 는 향후 취업하기를 원하는 것으로 나타났는데 그 이유는 생활비에 보탬이 돼서 라는 응답이 $54.9 \%$ 로 가장 높게 나타났다.

통계청이 발표한 2015 년 인구주택총조사에서도 60 세 이상의 생활비 원천(단일응답)에서도 본인과 배우자의 일과 직업이라는 응답자가 전체의 23.4\%로 가장 높게 나타나(Korea National Statistical Office, 2016) 생계형 근로를 하는 노인의 문제가 매우 심각한 상황이다. 하지만, 우리 사회는 노인이 일을 하면서 본인의 생활비를 마련하는 상황임에도 불구하고 노인의 빈곤문제를 개인 문제로 간주하고 있다. 이에 대해 더욱 적극적인 해결책이 모색되지 못하고 있다는 것은 노인빈곤의 상황을 더욱 절망으로 빠지게 할 수도 있다. 이제는 빈곤문제를 개인이 알아서 해결하도록 내버려 둘 수 없는 상황에 왔다.

한편, 저출산과 고령화로 우리 사회는 생산가능인구 (15-64 세)가 감소하기 시작하여 생산가능인구는 1966 년 $53.0 \%$ 이후 계속 증가하다가 2012 년 73.4\%로 정점이 이른 후 감소하여 2019 년 72.7\%, 2040 년 56.3\%, 2067 년에는 45.4\% 수준까지 낮아질 전망이다Korea
National Statistical Office, 2019). 이러한 인구 저출산 고령화는 기업입장에서는 인구감소를 대체하기 위한 인력활용방안으로 노인인력을 활용하는 방안이 적극적으로 검토되지 않은 한 기업의 생산성 자체에도 큰 위기로 작용할 수 있음을 직시할 필요가 있다. 실제 IMF는 한국이 현재 수준의 노동공급을 2050 년에도 유지하기 위해서는 은퇴나이를 11 세 늘려야 한다고 권고하기도 하였다.

이러한 문제 의식하에 본 연구는 인구 저출산과 고령화로 인한 기업에서 일할 인력수급의 문제를 노인고용으로 해결하는 하는 동시에 우리나라 노인의 고용문제를 해결하기 위한 노인의 일자리로 중소기업에서의 노인고용확대 방안을 제시하는 것을 목적으로 한다. 이를 위해 중소기업주를 대상으로 노인고용에 대한 현실과 문제점을 인터뷰하고 그 결과를 토대로 정책적 시사점을 제시한다.

\section{2. 노인 고용 현황과 제도}

\section{1. 고령자 고용 현황}

노인고용현황을 파악할 수 있는 통계는 55-64 세의 연령집단과 65 세 이상 연령집단을 구분하여 제시하고 있다. 이는 $\mathrm{OECD}$ 에서 규정하고 있는 고령근로자가 5564세이므로 국제적인 기준에 맞추어 통계자료를 분석하기 때문이다.

$\mathrm{OECD}$ 기준 고령근로자인 $55-64$ 세의 2020 년 1 월 기준 생산가능인구 중에 경제활동에 참가하고 있는 우리나라의 고령자 비율은 $65.7 \%$ 로 나타나고 있다.

Table 1: 55-64 Age Employment Status

\begin{tabular}{|c|c|c|c|c|}
\hline Category & $\mathbf{2 0 1 7}$ & $\mathbf{2 0 1 8}$ & $\mathbf{2 0 1 9}$ & $\mathbf{2 0 2 0 . 1}$ \\
\hline $\begin{array}{c}\text { Economic activity } \\
\text { participation rate }\end{array}$ & 69.1 & 68.8 & 68.9 & 68 \\
\hline Employment rate & 67.5 & 66.8 & 66.9 & 65.7 \\
\hline $\begin{array}{c}\text { Unemployment } \\
\text { rate }\end{array}$ & 2.4 & 2.9 & 3 & 3.5 \\
\hline
\end{tabular}

Table 2: Over 65 Age Employment Status

\begin{tabular}{|c|c|c|c|c|}
\hline \multirow{2}{*}{ Category } & \multicolumn{2}{|c|}{$\mathbf{6 4 - 6 9}$ Age } & \multicolumn{2}{c|}{ Over 70 Age } \\
\cline { 2 - 5 } & $\mathbf{2 0 1 0}$ & $\mathbf{2 0 1 7}$ & $\mathbf{2 0 1 0}$ & $\mathbf{2 0 1 7}$ \\
\hline $\begin{array}{c}\text { Economic activity } \\
\text { participation rate }\end{array}$ & 42.3 & 46.9 & 23.1 & 24.4 \\
\hline Employment rate & 41.1 & 45.5 & 22.7 & 23.7 \\
\hline Unemployment rate & 2.9 & 3.0 & 1.9 & 2.6 \\
\hline
\end{tabular}


2017 년 우리나라 60 대 후반 경제활동참가율은 46.9\%로 나타나고 있다(Table 2). 이 수치는 15-29 세 청년층의 경제활동참가율 $46.9 \%$ 을 상회하는 수준으로 우리나라 노인의 경제활동참가율이 높음을 알 수 있다. 2004 년과 2017 년 노인들의 산업별 취업자 비중을 살펴 보면, 절반이상이 농림어업에 종사하였던 2004 년에 비해 2017 년에는 보건, 복지업(대부분이 사회복지 서비스 업)과 경비원이나 청소부 등이 포함된 사업관리, 지원서비스업, 공공행정 순으로 취업자 비중이 증가되고 있음을 알 수 있다.

Table 3: The Change of Field Industry of the over 65 Worker

\begin{tabular}{|c|c|c|}
\hline \multicolumn{1}{|c|}{ Category } & $\mathbf{2 0 0 4}$ & $\mathbf{2 0 1 7}$ \\
\hline agriculture, forestry and fishery & 54.7 & 27.4 \\
\hline manufacturing business & 5.3 & 6.5 \\
\hline construction industry & 2.1 & 3.3 \\
\hline wholesale trade & 14.6 & 11.2. \\
\hline transportation and warehousing & 2.1 & 5.8 \\
\hline food and lodging industry & 3.5 & 4.8 \\
\hline real estate business & 3.1 & 3.7 \\
\hline project management & 4.8 & 10.3 \\
\hline public administration & 1.5 & 5.7 \\
\hline social welfare and sanitation & 0.4 & 9.3 \\
\hline organization, individual and repairs & 3.5 & 6.0 \\
\hline
\end{tabular}

Source : Korean National Statistical Office $(2004,2017)$

Economically Active Population Survey

\section{2. 노인 고용 지원제도}

노인고용과 관련된 정책은 고용노동부, 보건복지부, 행정안전부 등의 중앙부서에서 정책을 펼치고 있다. 고용노동부는 노동의 하나로 노인고용에 관한 정책을, 보건복지부에서는 노인의 복지증진을 위한 노인일자리로 노인고용에 관한 정책을 펼치고 있다.

고용노동부의 노인고용관련 법제로 가장 대표적인 것이 "고용상 연령차별금지 및 고령자 고용촉진에 관한 법률"이 있다. 이 법은 합리적인 이유없이 연령을 이유로 고용차별을 금지하고 있다. 또한, 노인고용촉진을 위한 노인적합직종의 선정과 공공부문의 노인우선고용, 정년 상향 및 정년후 재고용 촉진 등의 규정도 두고 있다. 다음으로 고용보험법에는 고용자고용촉진지원금, 임금피크제 지원금, 고용자 고용환경개선금, 중견인력 채취업지원사업 등을 실시하고 있다. 근로자직업훈련촉진법에는 노인직업능력개발을 실시할 수 있도록 규정하고 있다.

보건복지부의 노인고용정책에는 노인복지법에 노인일자리사업, 노인취업알선센터, 공동작업장 등을 명시하고 있으며, 시니어클럽,
시니어인텁쉽제도, 고령친화기업을 운영할 수 있도록 제도를 마련해 놓고 있다.

\section{3. 연구방법}

\section{1. 연구방법}

본 연구의 방법은 질적 조사방법으로 연구자가 직접 중소기업을 방문하여 기업주와 심층면접방식(In-depth interview)으로 진행하여 자료를 수집하였다.

기업에서의 노인고용을 확대하기 위한 방안을 알아보기 위해 인터뷰대상자를 중소기업주로 선정한 이유는 한국노인인력개발원이 수행한 경인, 부산 대구 산업단지에 상주하고 있는 5 인이상 300 인 이하 중소기업체 549 곳을 대상으로 조사한 결과, 중소기업의 32\%가 노인을 고용해 보니 괜찮다라는 조사결과가 시사하듯이(Korea Senior Human Resources Development Institute, 2013) 노인고용을 확대가 가능한 산업현장이 중소기업이라는 판단에서이다.

\section{2. 인터뷰 대상자 및 절차}

본 연구의 조사대상자는 중소기업주이며 인터뷰는 경기도경제단체연합회, 경기도노인일자리지원센터, 중소기업중앙회의 협조로 진행되었다. 기간은 2013 년 11 월 5 일부터 2013 년 11 월 18 일까지 총 15 명의 기업주를 대상으로 진행되었다(<table 4>).

Table 4: Interview list

\begin{tabular}{|c|c|c|}
\hline Number & Inverview Date & Type of Business \\
\hline 1 & 2013.11 .05 & Manufacturinf Business \\
\hline 2 & 2013.11 .05 & Manufacturinf Busines \\
\hline 3 & 2013.11 .07 & Service Industry(hospital) \\
\hline 4 & 1013.11 .07 & $\begin{array}{c}\text { Service Industry(car } \\
\text { maintenance) }\end{array}$ \\
\hline 5 & 2013.11 .12 & Service Industry(hospital) \\
\hline 6 & 2013.11 .12 & Service Industry(House keeping) \\
\hline 7 & 2013.11 .15 & Manufacturing Business(Food) \\
\hline 8 & 2013.11 .15 & Waste Industry \\
\hline 9 & 2013.11 .15 & Manufacturing Business(Food) \\
\hline 10 & 2013.11 .22 & Manufacturinf Business \\
\hline 11 & 2013.11 .22 & Waste Industry \\
\hline 12 & 2013.11 .23 & Manufacturinf Business \\
\hline 13 & 2013.11 .23 & Manufacturinf Business \\
\hline 14 & 2013.12 .13 & Manufacturinf Business \\
\hline 15 & 2013.12 .18 & Manufacturing Business(Food) \\
\hline
\end{tabular}


인터뷰 진행은 경기도경제단체연합회, 경기도노인일자리지원센터, 중소기업중앙회에서 연락처 제공에 동의한 기업주의 연락처를 연구자가 받은 후 기업주에게 사전에 전화를 하여 인터뷰가능여부를 확인하였다. 인터뷰가 가능하다고 응답을 한 기업주와 인터뷰시간을 약속하고 연구자가 직접 해당 기업에 1 회씩 방문하여 기업주와 $1: 1$ 로 인터뷰를 진행하였다. 인터뷰는 평균 1 시간에서 2 시간 소요되었다. 인터뷰는 사전에 연구자가 개방형 질문문항(open questionnaire)을 작성하여 기업주의 의견을 자유롭게 대답할 수 있도록 하여 진행되었다.

\section{4. 조사결과}

\section{1. 노인을 고용하지 않는 이유}

(일이 노인에게 적합하지 않음)

노인을 고용하고 있지 않은 가장 큰 이유는 일의 특성이 노인에게 적합하지 않기 때문이다. 기업주들은 업무의 특성상 대부분 속도감과 정확도를 요구하는 일로 노인이 하기에는 생산성과 정확도가 떨어지므로 오히려 외국인 근로자를 채용하는 것이 낫다는 견해를 보이고 있다.

근로자의 연령대가 30 대 중반에서 50 대 초반까지임. 단순포장작업에는 가능하지만, 라벨링 작업과 포장이 잘못되면, 다시 다 모든 부분을 꺼내서 검수해야 하는데, 다시 검수하는 것이 현실적으로 불가능한 일이어서 어르신 같이 시력이 안 좋고 실수가 많은 경우는 고용할 수가 없대경기도 $A$ 시 소재 기업 인터뷰 내용 중).

잡코리아, 워크넷 등에 생산직 직원 공고를 내면 실제로 40 대 이후가 휠씬 많이 지원을 하나, 젊은이들이 주로 채용되어 일을 하게 됩니다(경기도 $S$ 시 소재 기업 인터뷰 내용 중).

\section{2. 노인을 고용하는 이유}

(젊은 사람들을 채용할 수 없어서 노인고용)

노인을 고용하는 첫 번째 이유는 젊은 인력을 채용하기 어렵기 때문에 노인을 고용하는 것으로 나타났다. 이러한 업종은 흔히 이야기하는 $3 \mathrm{D}$ 업종으로 자원재활용, 청소, 경비, 주방일 등이다. 이 경우 열악한 근무환경과 급여 등 근무조건이 좋지 않기 때문에 젊은 인력들이 선호하지 않으므로 차선책으로 외국인 근로자나 노인을 채용하는 것으로 나타났다.
노인을 채용하는 이유는 젊은이가 오지 않으므로 하는 것이다. 젊은이들이 온다면 이들을 채용하겠지만 일이 더럽고 힘드니깐 오지를 않는다. 그나마 노인 분들 중에는 오시는 분들이 간혹 있으므로 채용을 하고 있다(경기도 $H$ 시 소재 기업 인터뷰 내용 중).

노인고용이유는 주방일은 젊은 사람들이 오지 않습니다. 보통 90 만원정도 드리는데, 이 윌급으로 매일 나와서 하는 젊은 사람은 없는데 어르신들은 참고 견디실 줄 알기 때문에 노인을 고용하고 있다. 업무의 특성상 오래 지속해서 환지들한테 일일이 식사를 배달해야 하는데 어르신이 계속 바뀌면 환자들한테도 좋지 않습니다경기도 $H$ 시 소재 기업 인터뷰 내용 중.

\section{(정년 후 재고용)}

두 번째 이유는 노인을 고용하고 있는 대부분의 경우는 정년 이후 재고용을 한 사례라고 할 수 있다. 기존의 오랜 경력과 서로 서로 업무와 인간관계에 익숙하기 때문에 필요한 일에는 재고용이 어렵지 않다는 의견을 주었다. 기업 입장에서도 노인의 특성을 알기 때문에 적절히 그에 맞추어서 일을 분배해서 노인이 같이 일을 하는 것으로 나타났다. 하지만, 이 경우 건강이 허락한다는 전제조건이 있기 때문에 노인 입장에서는 건강이 중요하다고 할 수 있다. 또한, 급여 등에 있어서도 종전 임금보다는 적게 지급하고 있는 것으로 나타났다.

60 세에 퇴사하여야 하나 성실하고 건강이 되면 65 세까지 재고용하고 있습니다. 현재에 64 세 되는 분도 60 세 때 재고용을 해서 현재까지 오고 있습니다. 직원 연령대는 30 대 후반부터 60 대 초반까지 골고루 있는데, 연령대별 성별(여성, 나이 드신 분)에게는 좀 더 수월한 일을 드리고 주 업무는 비교적 젊은 사람들이 하고 있습니대경기도 H시 소재기업 인터뷰 내용 중).

정년이 57 세인데 이번에 3 명도 재고용을 해서 일을 하고 있습니다. 전체 물류 부분을 빼고 약 110 명의 직원이 있는데 10 명 정도가 고령자로 임금피크제로 종전급여의 약 $70 \%$ 정도를 하고 있으며, 이 급여도 이미 최상에 올라가 있는 상태에서의 $70 \%$ 이므로 다른 곳에 비하면 많은 편이라고 할 수 있습니다. 회사입장에서 비용만을 따진다면 젊은 사람을 신규로 쓰는 것이 좋으나 그동안 30 40 년씩 회사에서 일을 같이 해온 사람들에 대한 인간적인 정도 중요합니다. 그래야 후배 직원들도 이런 것들을 보고 동기를 받을 수 있기 때문에 본인이 원하고 건강만 허락한다면 정년 이후 재고용을 계속해 오고 있습니다. 우리 기업은 제품 특성상 예전에는 기계가 했던 일. 예를 들어, 발효실의 온도를 맞추는 일을 지금은 기계가 하지만 예전에는 다 사람이 했던 일이라 이런 것들도 모두 정년 이후의 근로자가 많이 해 왔습니대경기도 $E$ 시 소재 기업 인터뷰 내용 중). 
(정부 노인고용 보조금 제도를 활용하여 고용)

세 번째 노인을 고용하고 있는 또 다른 형태는 중장년재취업제도나 시니어인턴십을 통한 고용인 것으로 나타났다. 우선 기업 입장에서는 검증되지 않은 노인을 고용하는 것이 꺼려지게 되는데, 제도를 통해서 급여도 보조 받으면서 노인을 고용해 보고 계속 고용할 것인지 아닌지를 검증할 수 있다는 것이다.

병원을 이용하는 주 고객이 50대, 60 대이어서 안내 등을 하는 업무를 어르신이 하면 좋을 것 같아서 알아보다가 노인일자리센터로 전화해서 구인을 의뢰하였습니다. 어르신은 안내데스크에 20 대도 함께 있기는 합니다. 안내도 하고, 진료예약 잘 안 보이시는 어르신은 대신 카드도 작성해 주고 음료 서비스 등등 전반적인 안내 업무를 하고 계십니대(경기도 $S$ 시소재 기업 인터뷰 내용 중).

원래부터 어르신들이 하던 일이기 때문에 어르신을 고용할 계획이었습니다. 구청에서 어르신 알선을 하는 것도 이용하곤 했는데, 시니어인턴십은 보조가 되니깐 시니어인턴십으로 하게 되었습니대경기도 $A$ 시 소재 기업 인터뷰 내용 중).

\section{3. 노인 고용 경로}

(노인일자리 관련 기관을 통해 고용)

노인을 고용하고 있는 업체는 시군 상담센터나 노인일자리센터 등 공공기관을 크게 신뢰하는 것으로 나타났다. 특히, 이런 기관에서 면접을 한 후 건강상태나 성격, 노인의 거주지 등을 파악해서 소개해 주기 때문에 기업 입장에서는 면접에 들어가는 에너지와 시간을 많이 절약할 수 있다는 의견을 주었다. 또한, 공신력 있다고 판단되는 기관에서 사람을 소개해 주고 있기 때문에 믿고 채용할 수 있다는 의견도 주었다.

주차관리 같은 경우도 50 대 이상을 고용하는 경우 잡코리아 등 취업 사이트를 이용하여 구인을 하기는 하는데 지원자가 너무 많아서(지역이나 자격 검증이 안 됨) 한번 걸쳐주어서 건강상태 등 이런 것들이 검증하고 지역도 근처 지역의 사람을 알선해 주니깐 좋습니대경기도 $S$ 시소재 기업 인터뷰 내용 중).

기업 입장에서는 어르신이 필요한 경우, 일반 구직 사이트보다는 한번 검증을 해준 노인일자리센터 같은 곳에서 연계를 해주는 것이 필요합니다. 일반 기업에서 운영하는 구인구직구직 사이트보다는 공공기관이기 때문에 더 신뢰가 생깁니대경기도 $S$ 시 소재 기업 인터뷰 내용 중).
(인터넷을 통한 노인고용의 어려움)

또한, 노인고용을 하는 방법에 있어서 노인들이 인터넷에 익숙하지 않기 때문에 인터넷 공고보다는 주변 지인이나 시군상담센터, 벼룩시장과 같은 지면을 통해야만 가능하다는 의견을 주었다. 이런 의미에서 노인일자리 확대를 위해서는 인터넷을 통한 신속하고 유연한 정보제공과 더불어 어르신들에게 일자리를 상담하고 알선하는 시군 상담센터와 같은 기관의 역할이 더욱 중요하다고 할 수 있다.

60 대 이상을 인터넷으로 공고하기가 어렵기 때문에 전화밖에 안 되어서 시청 등에서 제공하는 것이 필요하다고 생각합니다경기도 $A$ 시 소재 기업 인터뷰 내용 중).

현재 60 대 이상 어르신은 4명이 일을 하고 계시는데, 2 명씩 한 조를 이루어서 세차, 자동차 딜리버리 서비스, 급하게 필요한 사소한 부품 사오기 등의 일을 하고 계십니다. 단순노동이라 그 이전에도 60 대 이상 어르신이 했던 일인데 하시던 어르신이 이사를 하시면서 새로운 인력을 구하다가 작년부터 알기는 했는데, 정보 접근이 쉽지가 않아서 이용하지 못하고 있었습니다. 이번에는 시청으로 연락해서 노인을 채용하게 되었습니대경기도 $A$ 시 소재 기업 인터뷰 내용 중).

\section{4. 기업안에서 노인들의 강점}

\section{(근면함과 성실함)}

노인들의 강점이라고 하면 첫째, 근면함과 성실함을 가장 많이 이야기 하였다. 노인들은 시간관념이 철저하고 맡은 업무를 정확히 하려고 하기 때문에 기업 입장에서는 특별히 할 일이 없다는 것이다. 또한, 노인들은 젊은이들과는 달리 자기 업무 이외에도 눈에 보이면 하기 때문에 다른 직원들한테 솔선수범이 되고 있다는 것이다. 이것은 공동체 의식과 가족주의 의식이 강하게 몸에 베인 노인세대의 특성이라고 할 수 있을 것이다. 따라서 이러한 성향을 가지고 있는 노인들을 기업 입장에서 고용하게 되면 매우 고맙다는 것이 기업의 반응이다.

어르신의 솔선수범 등이 장점이 되고 있습니다. 요즘 같이 낙엽이 많이 떨어지고 그러면 본인 업무가 아닌 데도 청소를 하시고 하니깐 우리 입장에서는 좋습니대경기도 $A$ 시 소재 기업 인터뷰 내용 중).

어르신들은 성실한 게 가장 큰 장점입니대경기도 $E$ 시 소재 기업 인터뷰 내용 중).

어르신들은 시간관념이 철저한데 그것이 큰 장점입니대경기도 H시 소재기업 인터뷰 내용 중). 
(선배로서의 경험과 지혜를 젊은이에게 전수)

일부 업종에서 나타난 결과이지만 노인이기 때문에 가능한 장점도 있는 것으로 나타났다. 대표적으로 젊은 사람들이 갖기 어려운 지혜를 후배들에게 전수하는 것과 노인들이 본인이 겪으면서 느낀 어려움을 일을 할 때 활용하여 서비스 대상자에게 따뜻하게 대하는 것 등이 그 예가 된다. 회사 입장에서도 이러한 것들이 매우 필요하기 때문에 적극적으로 노인에게 이러한 부분의 역할을 해 줄 것을 요구하는 것으로 나타났다.

노인이 갖고 있는 노하우를 후배들에게 전수하는 것이 중요한 일 중의 하나입니다. 이것은 경험으로만 할 수 있는 것이기 때문에 오랫동안 일을 한 사람이 노하우를 잘 전수해 주는 것이 회사 입장에서는 매우 중요합니다. 사람들이 모르는 문제가 있으면 모두 이 어르신에게 전화해서 물어봅니다. 회사 입장에서도 재 고용된 근로자분 들에게는 회사의 후배들에게 모범이 되고, 지혜를 전수할 수 있도록 요청을 하고 있습니대(경기도 $E$ 시 소재 기업 인터뷰 내용 중).

60 대 이상 되신 분들도 현재 일을 하고 계신 분들도 있습니다. 50 대부터 시작하셔서 일이 능숙하시니깐 60대가 되셨어도 계속 하고 계십니다. 이런 분들은 적극적으로 추천하게 되고, 직원 교육 등에도 교육 강사로도 역할을 하고 계십니대경기도 $S$ 시 소재 기업 인터뷰 내용 중).

\section{5. 기업안에서 노인들의 단점}

(어른으로 대접받으려 함)

노인을 고용할 경우에 단점은 어른으로 대접을 받으려고 하기 때문에 조직 운영상 어려운 점이 나타나거나 젊은 사람들과 마찰이 일어나는 경우가 있다는 것이다. 예전처럼 젊은이들이 노인이라고 대접하는 것도 아니기 때문에 이런 경우는 조직을 전체적으로 운영함에 있어 어려움이 있다는 의견을 주었다. 이런 문제점을 방지하기 위해 인터뷰 대상 기업들은 정확하게 업무를 분담하여 조직을 운영하는 것으로 나타났다.

오랜 세월 한 분야의 전문가로 살아오셨을 뿐만 아니라 연세가 있으시기 때문에 고용 후 함께 일하는 직원들과 동등한 입장이 아닌 조금은 상사의 입장에서 일하시는 경우가 다수입니대경기도 $Y$ 시 소재 기업 인터뷰 내용 중).

노인들이 일을 젊은 사람들한테 미룬다거나 하는 것을 미리 방지하기 위해 정확하게 업무를 분담하여 역할을 책임 지웁니대(경기도 $S$ 시 소재 기업 인터뷰 내용 중).
(생산성이 떨어지고 융통성 있게 인력활용 못함)

노인의 특성상 생산성이 떨어진다는 것이다. 야근 같은 것은 불가능하고 기업 입장에서는 근무시간과 작업량을 정확하게 지켜서 일을 시켜야 하기 때문에 젊은이들처럼 융통성 있게 직원을 사용할 수 없다는 것이다.

어르신은 아무래도 피로가 금방 풀리지가 않아 작업량이 많이 몰리는 경우, 야근 등으로 무리를 하게 되면 일을 지속하실 수가 없기 때문에 정시에 퇴근시켜 드리고 있습니다. 회사 전체적으로 너무 고령자가 많으면 생산성이 떨어지는 것이 사실입니대경기도 $S$ 시 소재 기업 인터뷰 내용 중).

(업무의 정확성이 떨어짐)

노인의 경우 노화로 인해 시력 등도 나쁘기 때문에 정확도가 떨어진다는 것이다. 이러한 부분은 정확도가 매우 필요한 직종에서 노인을 채용할 수 없는 경우와는 다르지만 기업 입장에서는 한 번씩 확인하는 작업을 해야 하는 번거로움이 있는 것으로 나타났다.

단점은 속도가 느리긴 합니다. 속도를 요하는 직업이 아니니깐 괜챃지만 느려서 일을 진행하는 데 불편한 것이 있기는 합니다. 그리고 각 환자 별 식단에 맞게 배달이 되어야 하는데, 눈이 잘 안 보이시니깐 기끔씩 식사가 잘못 배달되는 경우가 있어 식사 배달 후에는 꼭 확인하는 작업을 해야 합니대경기도 $S$ 시 소재 기업 인터뷰 내용 중).

\section{(건강 위험)}

노인고용을 함에 있어서 기업주 입장에서 가장 큰 걱정은 건강위험이다. 실제로 노인을 고용하였다가 건강이 좋지 않으셔서 일에 차질을 겪어 본 경우도 있고, 무리를 해서 건강이 나빠지실 것을 우려하는 것으로 나타났다. 건강이 안 좋은 경우 결근으로 이어지고 이것이 곧 기업의 생산성과 직결되기 때문에 기업입장에서는 이 부분을 큰 부담으로 생각하는 것으로 나타났다.

건강이 중요합니다. 한번은 몸이 안 좋으셔서 결근하시는 어르신이 있었는데 그것은 다른 업무에까지 영향을 주므로 성실, 건강 정도가 중요한 것 같습니다. 새로운 업무는 적응하는데 시간이 좀 걸리고 여러 번 해야 하니깐 이 부분도 불편하기는 하지만...경기도 $A$ 시 소재 기업 인터뷰 내용 중).

건강과 열정만 허락하면 나이는 상관없는데, 이 부분이 조금 문제가 있습니다. 한 분은 건강이 안 좋으서서 자꾸 결근하고 하서서 기업에서 고생을 한 적도 있습니다. 이 부분이 제도적으로 보완이 되었으면 좋겠다는 생각을 했습니대(경기도 $S$ 시 소재 기업 인터뷰 내용 중). 


\section{6. 노인고용시 조직운영 특징}

(노인의 업무 적응과 젊은이와의 융화에 힘슴)

노인 고용시 회사입장에서는 변화의 적응이 쉽지 않다는 것과 젊은 사람들과의 관계를 적절하게 잘 유지하는 것에 신경을 쓰는 것으로 나타났다. 이 부분이 성공적으로 이루어지면 노인고용을 할 수 있지만, 그렇지 않은 경우는 노인을 고용하지 않는 것이 기업의 입장이었다.

베이비부머 세대를 과거 3 명 정도 채용해 보았는데, 모두 3 4 일정도 하고 나갔습니다. 적응문제가 가장 큽니다. 젊은 사람들은 한 1 주일 정도 데리고 다니면 교육이 가능한테, 용어라든가 하는 것이 노인 분들이 익숙해지는 데는 오래 걸립니다. 또한, 회사 생활적인 측면에서 젊은 사람들과 융화가 매우 어려웠습니대경기도 $S$ 시 소재 기업 인터뷰 내용 중).

(노인과 젊은이들간의 정확한 역할 분담)

노인과 젊은이들 사이의 노력도 중요하지만, 회사 조직 내에서 노인에 대한 호칭 사용과 노인과 젊은이들 간의 정확한 역할 분담도 중요한 것으로 나타났다. 노인을 고용하고 있는 기업은 노인에게 젊은이들에 대한 모범을 보여줄 것을 요구하기도 하지만 다른 한편에서는 노인에 대한 예의를 갖출 수 있는 조직 문화를 만들고 있었으며, 젊은이들과의 마찰을 예방하기 위해 정확한 역할 분담을 하고 있는 것으로 나타났다.

젊은 사람들이 주로 자동차정비를 하고 있으므로 호칭은 "주임님"으로 해서 젊은 사람들하고 별 어려움 없이 하도록 하고 있습니대경기도 $S$ 시소재 기업 인터뷰 내용 중).

직원 연령대는 30 대 후반부터 60 대 초반까지 골고루 있는데, 연령대별 성별(여성, 나이 드신 분)에게는 좀 더 수월한 일을 드리고 있습니다. 주 업무는 비교적 젊은 사람들이 하고 있습니대경기도 S시 소재 기업 인터뷰 내용 중).

(노인의 특성에 맞게 보조적인 일/경험에 맞는 일에 활용)

노인을 고용하고 있는 기업에서는 이미 노인의 특성과 기업의 상황을 감안하여 노인을 고용하고 있는 것이기 때문에 특별한 어려움이 없다는 것이 대부분의 의견이었다. 노인을 고용하지 않고 있는 기업에서는 낮아진 생산성에 대한 보상 등을 염려하였으나 오히려 현재 노인을 고용하는 기업은 노인의 특성을 고려하여 주된 일자리보다는 보조적인 일자리로 노인인력을 활용하거나 또는 노인이 오랜 경험으로 몸에 체득된 감각적으로 할 수 있는 일을 하고 있기 때문에 별 어려움이 없는 것으로 나타났다.
현재 60 대 이상 어르신은 4명이 일을 하고 계십니다. 2 명씩 한 조를 이루어서 세차, 자동차 딜리버리 서비스, 급하게 필요한 사소한 부품 사오기 등의 일을 하고 계십니다. 정비 등의 주된 일은 젊은 사람이 하지만 그때그때 보조적으로 노인들이 해 주어야 할 일들이 있습니대경기도 $A$ 시 소재 기업 인터뷰 내용 중).

우리 일은 발효가 잘되는 게 제일 중요한데, 발효단계마다 온도나 습도가 같다고 해서 발효가 똑같은 게 아닌데, 이것은 색깔이나 농도 이런 것들을 통해서 오감으로 감각적으로 발효가 잘됬다 좀 문제가 있다 하는 것을 발견할 수 있기 때문에 경험이 많은 노인 분들만이 할 수 있는 일이죠(경기도 $E$ 시 소재 기업 인터뷰 내용 중).

\section{7 노인고용시 필요한 제도}

(장기적인 안목에서 노인고용창출 큰 회사를 지원)

단순히 얼마를 지원하기보다는 장기적인 안목에서 시장경제 속에서 지속적인 일자리 창출이 중요하기 때문에 고용창출 효과가 큰 회사를 좀 더 성장할 수 있도록 지원하는 제도가 중요하다는 의견이 피력되었다. 이것은 노인 일자리만을 창출하는 것에 한정하기 보다는 전체적으로 일자리를 확대하는 과정에서 노인도 젊은이들과 함께 같이 일을 할 수 있도록 성장 가능성이 큰 회사를 지원하는 것을 의미하는 것이다. 노인일자리 창출 과정에서 확실히 성장이 가능한 회사에게 지원을 한다면 장기적으로 국가 경제에도 도움이 될 수 있으므로 이러한 제도를 적극적으로 모색할 필요가 있다는 의견을 주었다.

성장 가능성이 높아서 고용창출 효과가 큰 회사를 지원하는 시스템이 절실합니다. 이에 대해서는 면접 등을 통해 충분히 검증이 가능합니대경기도 $S$ 시소재 기업 인터뷰 내용 중).

우리 같은 5 인 미만의 영세한 업체는 시니어 인턴십에서 지원하는 돈이 크게 보탬이 되고 있습니다. 어르신이 하기에도 적합한 업종이므로 회사가 좀 더 성장해서 노인도 고용할 수 있는 쪽으로 제도를 지원해 주었으면 합니대경기도 $S$ 시 소재 기업 인터뷰 내용 중)

(노인재고용 및 노인고용시 임금보전 등의 정책이 필요)

기업들은 노인을 신규로 고용하기는 어렵지만 재고용은 가능하다는 의견이 많았다. 재고용은 가능하지만 해결해야 할 과제는 젊은이를 채용할 경우에 비해 임금은 높고 생산성이 낮은 문제를 어떻게 해결할 수 있느냐 하는 것이었다. 
근로자가 10 20 년 일을 하다가 60 세가 된 경우 재고용은 가능합니다. 이 경우 연공서열임금을 폐지하고, 낮아진 생산성만큼을 임금피크제 등으로 급여를 낮추어야 가능할 뿐만 아니라 젊은 인력을 채용하지 못하는 것만큼의 인센티브가 있어야 합니대경기도 $A$ 시 소재 기업 인터뷰 내용 중).

40 대 후반은 2 교대를 매우 어려워하였는데, 오히려 60 대 이상은 2 교대를 충분히 인내하실 수도 있을 것 같습니다. 작업 보드가 매우 무거운데 충분히 체력이 가능하고, 주야간 근무를 인내하실 수 있다면 60 대 채용도 가능합니다. 이 경우 기업 입장에서는 어르신들이 일을 잘할 수 있는지 검증이 필요하므로, 기업체와 정부보조금으로 매칭 펀드식으로 1 달간 고용해 보고, 정규직으로 채용하는 제도가 있다면 우리 회사는 충분히 이용할 의사가 있습니대경기도 $S$ 시 소재 기업 인터뷰 내용 중).

(구인, 구직싸이트 활용이 용이하도록 개선 필요)

대부분의 기업에서 워크넷이라는 고용노동부에서 운영하고 있는 구인-구직 사이트 또는 잡코리아와 같은 인터넷 사이트를 많이 이용하고 있는 것으로 나타났다. 하지만 이들 정보는 너무 이용하기가 어렵다는 의견을 주었다.

우선, 고용 시 워크넷을 이용하지만, 회사 특성상 고용할 수 있는 대상이 많지 않습니다. 명확히 어떤 경우 고용이 가능한지 한눈에 알아볼 수 있고 쉽게 찾아서 확인할 수 있는 경우가 미흡하다고 생각됩니대경기도 $Y$ 시 소재 기업 인터뷰 내용 중).

(이용하기 쉽고 편리한 노인관련 고용제도 필요)

기업 입장에서 노인 고용을 확대하기 위한 보조금 제도를 이용하기에 그 절차가 복잡하고 너무 까다롭다는 이야기를 주었다. 그렇게 딱 맞는 조건을 찾아서 지원하기보다는 보다 융통성 있게 제도를 운영할 필요가 있음을 지적하고 있다.

정책 쪽으로 애기를 하자면 고용을 할 수 있는 벽이 높습니다. 제한을 하는 내용이 너무 많고 쉽게 고용을 할 수 없을 정도로 벽이 높다는 뜻입니다. 우리와 같은 중소기업에서는 사실 알아보고 문의전화도 하지만 매번 그 일을 반복하기에 많이 지치기도 합니다. 이런 것들을 한눈에 알아볼 수 있고 쉽게 고용을 할 수 있도록 해주었으면 합니대(경기도 $Y$ 시소재 기업 인터뷰 내용 중).

고령친화기업의 경우, 이미 고령자를 70\% 이상 고용한 기업에 해당이 되는데 실제 현장에서 노인들만을 70\% 이상 고용하고 있는 회사는 거의 없습니다. 우리 회사 같은 경우는 주된 일자리로 청년 1 명당
보조역할을 하는 노인을 1 명 내지 0.5 명까지 채용할 수 있는데, 이렇게 되려면 전체적인 준비가 필요한데 당장 $70 \%$ 이상인 경우만 고령친화기업을 신청할 수 있으니 우리 회사와 같이 노인인력의 비율이 높은 회사조차도 신청할 수가 없는 제도입니대경기도 $S$ 시 소재 기업 인터뷰 내용 중).

\section{8 노인고용의사}

(기업에 이익이 된다면 노인고용에 대한 편견은 없음)

기업은 이윤추구가 가장 기본적인 목적이므로 절대적으로 노인에 대한 편견을 갖고 있지도 않고, 기업에 이익이 된다면 노인을 적극적으로 채용할 의사가 있는 것으로 나타났다. 또한, 정부에서 지원하는 보조금이 도움이 안 되는 것은 아니지만, 보조금보다는 회사에 이익을 줄 수 있는가 없는가가 노인채용 여부를 결정하는 것으로 나타났다.

병원 입장에서는 월 45 만 원이라는 돈 때문에(시니어 인턴십) 어르신을 채용하지는 않습니다. 어르신이 일을 잘하시고, 고객들도 많이 좋아하니깐 채용을 하고 있는 것입니대경기도 $S$ 시 소재 기업 인터뷰 내용 중).

원래부터 어르신들이 하던 일이기 때문에 어르신을 고용할 계획이었습니다. 원장님과 이야기할 내용이지만 잘하시니깐 계속적으로 고용할 계획을 가지고 있습니다(경기도 $A$ 시 소재 기업 인터뷰 내용 중).

중장년 인턴십으로 연계해서 하니깐 기업에서는 도움이 많이 됩니다. 계속적으로 매장관리와 단순수리업무에 대해서는 어르신을 고용할 계획을 갖고 있습니대경기도 $E$ 시 소재 기업 인터뷰 내용 중).

(보조적인 일자리에 노인인력 활용 가능성이 높음)

기업주들은 노인 일자리, 청년 일자리 이렇게 구분하기보다는 생산성 측면에서 주된 일자리는 청년이 하지만, 회사 내에서 보조적인 일자리는 노인이 충분히 할 수 있으므로 청년 일자리와 노인 일자리를 모두 성장할 수 있도록 건전한 기업마인드를 갖고 있으면서 성장가능성이 큰 회사를 지원하는 제도가 궁극적으로 일자리 창출에 기여할 수 있다는 입장을 나타냈다.

젊은 사람들은 주 업무를 담당하고 어르신들은 업무보조 현장보조 업무를 하면 되므로, 회사가 성장해서 젊은 사람들의 고용도 창출하고, 어르신 고용도 창출하는 그런 시스템으로 가야 합니다경기도 $S$ 시 소재 기업 인터뷰 내용 중). 
개인적인 생각으로 65 세까지는 충분히 일을 할 수 있다고 생각하고, 50 대에 좋은 인력들이 퇴직을 하는 것은 국가적으로도 큰 낭비라고 생각합니다. 현재까지 총 7 명의 중장년인턴을 채용하였는데 그 중에 3 명은 계속적으로 고용을 하고 있습니다. 이러한 제도를 통해 계속적으로 중장년들을 채용할 수 있도록 해야 합니대경기도 $S$ 시 소재 기업 인터뷰 내용 중).

\section{(노인고용에 대한 기업주 마인드가 중요함)}

뿐만 아니라, 정년 후 재고용이 활성화되기 위해서는 노인고용에 대한 적극적인 의지를 갖는 기업주의 마인드가 무엇보다 중요한 것으로 나타났다.

노인이 원하고 본인이 건강이 허락하는 한 회사에서 재고용을 하는 것이 바람직하다고 생각합니다. 정부의 제도도 중요하지만, 기업주의 마인드 그리고 회사의 문화가 중요합니다경기도 $E$ 시 소재 기업 인터뷰 내용 중).

\section{5. 결론}

이상의 연구결과를 토대로 본 연구의 결론을 제시하면 다음과 같다.

첫째, 노인을 고용하는 경우는 정년 후 재고용으로 이미 검증된 인력을 활용하거나 정부의 임금보조제도를 활용하여 노인을 채용해 보고 적합하면 노인을 계속적으로 고용하는 것으로 나타났다. 반면에 노인이 일에 적합하지 않은 경우 아예 고용을 하지 않고, 고용을 하더라도 젊은이들이 하지 않기 때문에 고용을 하는 형태로 나타났다. 또한, 노인을 고용함에 있어서의 단점으로 지적된 정확하지 않음, 젊음이들과의 융화문제, 어른으로 대접받고 싶어함, 건강위험 등은 기업입장에서 고용에 따른 위험부담이 큰 것으로 나타나고 있다. 이것은 기업현장에서 노인 인력이 젊은이들과의 경쟁에서 뒤질 수 밖에 없는 나이의 한계가 분명히 존재함을 알려준다고 할 수 있다. 하지만, 노인을 계속 고용하는 경우 이미 그 업무의 숙련도에서 노인이 적합하다는 것과 노인의 노인고용의 장점에서 강조되었던 노인세대가 가진 근면함과 성실함 그리고 선배로서의 경험과 지혜를 젊은이에게 전수하려고 하는 점 등은 기업 입장에서 노인 고용의 시너지 효과를 발휘하고 있는 것으로 증명되었다. 따라서 향후 중소기업에서 노인고용을 확대하기 위해서는 노인들이 가지 선배 근로자로서 후배들에게 전수할 지혜를 계발하고 젊은이들에게 모범이 될 수 있는 태도를 향상시키는 교육 등을 통해 계속적으로 기업에서 일을 할 수 있는 자질을 계발하도록 하는 프로그램이 필요할 것이다.
둘째, 노인채용 경로를 보면, 인터넷 구인, 구직 싸이트 보다는 노인일자리 관련 기관에서의 소개가 더 많이 현장에서 활용되었다. 또한 정부에서 시행하고 있는 보조금 제도 등을 통해 노인을 채용해 보면서 노인의 특성을 이해하고 계속 고용으로도 이어지고 있었다. 하지만 이러한 제도를 이용함에서 있어서 절차가 까다롭고 복합해서 이용하는데 어렵다는 의견도 같이 존재하였다. 이것은 노인일자리 관련 기관이 그 역할을 더욱 확대하여 노인고용에 적극적으로 할 수 있도록 제도가 확대됨과 동시에 이들 제도의 이용이 수요자인 기업이 보다 편리하게 이용할 수 있도록 정비될 필요한 있음을 시사한다.

셋째, 기업주와 노인 모두의 인식의 개선이 필요하다. 본 연구의 결과에서 노인의 주된 채용경로는 기업에서의 정년 후 재고용형태가 가장 많은 것으로 나타났다. 우리나라에 계속고용제도가 법으로 없는 것은 아니다. 중요한 것은 이것을 실천하는 기업주의 의지이다. 선행 연구에 의하면, 연령차별금지법과 관련해 정년제 폐지로 은퇴의 지연효과가 확실히 존재하기는 하지만 고령자 신규고용에는 통계적으로 유의미한 효과를 보이지 않는 것으로 나타났다. 실제로 기업에서는 연령으로 인한 고용차별은 금지되어 있다 하더라도 사용자들은 고령자의 조기퇴직을 유도하기 위한 다양한 방법들을 사용하고 있는 것이 현실이다.

노인을 고용하고 있는 기업에서는 노인의 특성에 맞게 노인의 근로여건을 조성하고 있기 때문에 노인고용에 있어서 큰 어려움이 없다는 의견을 주었고 일부 기관에서는 소비자들이 노인의 작업속도가 느린 것을 보완하기 위해 뒤에서 노인의 일을 도와서 소비자의 속도감에 맞춘다는 의견도 주었다. 따라서 노인일자리창출을 위해서는 기업주도 노인이라는 선입견을 갖기 보다는 노인의 특성에 맞는 일을 현장에서 창출할 수 있는 인식 전환이 필요하다. 노인에게는 젊은 사람들한테 대접받지 않고 스스로 기업의 연장자로서의 일을 하려는 태도가 요구된다. 본 연구의 결과에서도 지혜를 후배에게 전달하고 솔선수범을 하는 경우는 노인고용이 이루어지지만 대접받으려 한다든지 하는 경우는 노인 고용이 이루어지지 않고 있었다. 이는 노인들 또한 변화하지 않으면 노동현장에서 살아남을 수 없다는 것을 직시하여 노인 스스로의 변화 또한 필요할 것이다.

마지막으로 사회적으로 노인고용에 대한 인식을 전환할 필요가 있다. 노인고용에 있어 가장 큰 장애 중에 하나는 노인이 일을 하는 것에 대한 거부감이다. 이미 선진국들은 노인일자리와 청년일자리는 별개임이 증명되고 노인이 근로하는 것이 국가 경제적으로 이익임을 검증해 내고 있다. 예를 들어, 독일, 프랑스는 90 년대 중반까지 노인들을 조기퇴직 시키고 노인들이 조기 퇴직하고 나서 남은 일자리를 청년들에게 돌리겠다고 정책을 정했으나 노인이 조기 퇴직함으로 인해 연금재정부담만 늘어나고 그 일자리가 청년들에게 가지 않는 것이 증명되어 이제는 더 이상 이 정책을 채택하지 않고 있다. 국내에서도 노인일자리와 청년일자리는 서로 별개로 존재하고 
있다는 것이 증명되었으며, 본 연구의 결과에서도 노인이 할 수 있는 일과 젊은이가 할 수 있는 일이 분리되는 것으로 나타났다. 따라서 노인일자리창출이 청년일자리를 잠식한다는 사회적 인식을 개선할 필요가 있다.

노인의 준비되지 않은 은퇴는 노인의 삶의 질을 열악하게 만는다고(Atchley, 1982; Bianchini, \& Borella, 2016; Bonsang, Adam, \& Perelman, 2012; kim, 2015; Kim, 2019) 보고되는 만큼 노인의 고용을 지원할 수 정책이 필요하며 궁극적으로 중소기업에서의 노인의 근로는 단순노무직이 아닌 노인들이 기업에서 정규직으로 일함으로써 노인빈곤을 해결할 수 있는 양질의 일자리로 거듭나야 할 것이다.

\section{References}

Atchley, R. C. (1980). The social forces in late life (2nd ed). Belmont, CA: Wadsworth.

Atchley, R. C. (1982). Retirement as a Social Institution. Annual Review of Sociology, 8(1), 263-287.

Baker, R., Dowling, Z., Wareing, L. A., Dawson, J., \& Assey, J. (1997). Snoezelen: Its long-term and short-term effects on older people with dementia. British Journal of Occupational Therapy, 60(5), 213-218.

Bianchini, L., \& Borella, M. (2016). Retirement and memory in Europe. Ageing and Society, 36(7), 1434-1458.

Bonsang, E., Adam,S.,\& Perelman, S. (2012). Does Retirement Affect Cognitive Functioning? Journal of Health Economics, 31(3), 490-501.

Byun, S. E.(2018)..Evaluating Information Technology Systems Using Consumer Surveys: The Role of Personal Product Knowledge. The Journal of Asian Finance, Economics and Business, 5(4), 117-125.

Ishak, Y., Ismail, A. Abdullah, A. A. Samsudin., A. \& Mohamed, K. R.(2018). Mediation of Distributive Justice on Dyadic Relationship between Leaders and Followers with Personal Outcomes, The Journal of Business, Economics, and Environmental Studies, 8(4), 29-35.

Jang, S. Y., Gu, S. H., Kim, D. S., \& Ping, W. (2014). Development of an Overseas Real Estate Valuation Model
Considering Changes in Population Structure. Journal of Distribution Science, 12(3), 65-73.

Kim, J. J. (2019). A Study on the Retirement Satisfaction according to the General Characteristics of Retired Elderly. The International Journal of Industrial Distribution \& Business, 10(12), 25-34.

Kim, J. J., \& Youn, M. K. (2015). Correlation analysis of self employment of retirees using demographic characteristics of the retail establishment. International Journal of Industrial Distribution \& Business, 6(4), 17-22.

Kim, J. J. (2017). A Study on the Financial Stress and Retailer Selection of the Elderly. Journal of Distribution Science, 15(6), 25-36.

Kim, J. J., \& Go, S. (2017). Impact of Railroads on Local Economies: Evidence from U.S. History. Journal of Distribution Science, 15(4), 25- 32.

Korean National Statistical Office (2016). 2015 Population and Housing Census. Retrieved Feburary 27, 2016, from http://www.kostat.go.kr/portal/korea/kor_nw/3/index.board?b mode $=$ read\&aSeq $=359282$

Korean National Statistical Office (2019). Population Status of the World and Korea Reflecting Special Population Estimates for 2019. Retrieved Setepmber 27, 2019, from http://kostat.go.kr/portal/korea/kor_nw/1/1/index.board?bmod $\mathrm{e}=\mathrm{read} \& \mathrm{aSeq}=377701$

Lee, J. W. (2015). Antecedents of acceptance of social networking sites in retail franchise and restaurant. business. Journal of Asian Finance, Economics and Business, 2(1), 29-36.

Lee, M. H. (2019). Does Population Aging Contribute to Increased Fiscal Spending? The Journal of Business, Economics, and Environmental Studies, 9(4), 23-28.

OECD (2018). Pension at a Glance 2018. ISSN: 23090766 https://doi.org/10.1787/23090766

Oh, M. J. (2018). Does Social Exclusion Cause People to Make More Donations? The Journal of Asian Finance, Economics and Business, 5(2), 129-137.

Ranzijn, R. (2002). The potential of older adults to enhance community quality of life: Links between positive psychology and productive ageing. Ageing International, 27(2), 30-55.

Ryu, J. S., Swinney, J., Muske, G., \& Zachary, R. K. (2012). Business Orientation, Goals and Satisfaction of KoreanAmerican Business Owners. The Journal of Business, Economics, and Environmental Studies, 2(2), 5-11. 